\title{
GLOBALISATION AND NEW REALITIES FOR MULTINATIONAL ENTERPRISE- DEVELOPING HOST COUNTRY INTERACTION
}

\author{
Rajneesh Narula \\ and \\ John H. Dunning \\ Revised version: 14 September 1998
}

Corresponding author:

Dr. R. Narula

ESST,

University of Oslo

PB 1108 Blindern,

N-0317 Oslo

Norway

Fax: +47 22858984

Phone: +4722858719

e-mail: rajneesh.narula@esst.uio.no 


\section{$\underline{\text { ABSTRACT }}$}

Globalisation has changed economic realities. First, the competences of MNEs are becoming increasingly mobile and knowledge-intensive. MNEs thus give more attention to the availability and quality of the created assets of alternative locations. Second, among developing countries there are now considerable differences between the 'catching-up' countries (e.g., NICs) and 'falling behind', less-developed countries (LDCs). These developments have changed the opportunity sets of both parties. FDI-based development strategies are now commonplace among LDCs, but there is also increased competition for the 'right' kinds of investment. In general, the balance in bargaining power has shifted in favour of the MNE, and LDCs increasingly need to provide unique, non-replicable created assets to maintain a successful FDI-assisted development strategy . 


\section{GLOBALISATION AND NEW REALITIES FOR MULTINATIONAL ENTERPRISE- DEVELOPING HOST COUNTRY INTERACTION}

\section{INTRODUCTION}

Fundamental changes in political ideologies and economic systems among a large number of developing countries have led to dramatic shifts in the way governments of these countries perceive their interests and those of their constituents. As a result, there are now a wide variety of attitudes and actions by governments towards MNE activity. This heterogeneity of responses is not, in itself, surprising, given the different stages of development, political ideologies, cultural norms, history and institutional infrastructure of countries. It is, nonetheless, possible to generalise that the relations between national governments and multinational enterprises (MNEs) in the 1990s, if still uneasy, are more favourable than they have been for many years (Dunning 1998).

The present thrust towards MNE-friendly attitudes by governments dates back to the early 1980s, and corresponds to a variety of changes in the world economy which have been generically (although not always appropriately) described as 'globalisation'. Economic globalisation refers to the increasing cross-border interdependence and integration of production and markets for goods, services and capital. This process leads both to a widening of the extent and form of international transactions, and to a deepening of the interdependence between the actions of economic actors located in one country and those located in other countries (Dunning 1997a). It is perhaps best demonstrated by the huge increases in the transnational flows of both portfolio and direct investment, and in the number of cross-border strategic alliances. ${ }^{1}$ The role of multinational firms has been central in the growth of these phenomena.

One of the primary consequences of globalisation has been the growing convergence of income levels, consumption patterns and institutional structures, both within the industrialised countries, and between the more advanced developing countries; and also the increasing significance of their intra-firm trade in goods and services (Fukuyama 1995, Landes 1998). The two primary determinants of globalisation have been, inter alia, (i) the rapid introduction and implementation of new technologies, particularly information and computer technologies (ICTs), and the consequential fall in cross-border communication and organisational costs; and (ii) the renaissance of democratic capitalism and the liberalisation of many domestic and international markets. 
Globalisation has influenced both the nature of the location specific (L) advantages of countries and the ownership specific $(\mathrm{O})$ advantages of firms, and the opportunity sets facing the governments of the former and the managers of the latter. Inter alia, value-adding activities have become increasingly knowledge-intensive, not just in high-technology sectors, but also in low-technology sectors, and even in those sectors that were previously regarded as labour-intensive. Both sets of institutions have thus adjusted their strategies and policies to the realities of the new global environment. First, the nature of MNE activity has undergone a marked shift, as firm-specific intangible assets - especially intellectual capital - have become more mobile. Second, national governments are now increasingly competing with each other to attract mobile investment. As the significance of immobile L advantages in influencing the competitive position of MNEs has increased (Porter 1994, 1996), so too have the bargaining stakes of the two parties.

However, globalisation has not affected all countries and regions to the same extent or in the same way. Indeed, it has resulted in a widening in the created assets ${ }^{2}$ and income gap between the industrialised countries and a handful of wealthier developing countries on the one hand, and the poorer developing countries at the other. The focus of this paper is on the latter group of countries which have 'fallen behind'. One of the consequences of the polarisation of countries is that the bargaining position (and the opportunity costs) of the national governments of these countries vis-à-vis foreign direct investors varies considerably between these different groups of countries. For example, different kinds of $\mathrm{L}$ and $\mathrm{O}$ advantages are associated with inward MNE activity in (say) Taiwan, compared to Bangladesh. In addition, the motives, modes and extent of MNE involvement vary considerably by the stage of economic development (Dunning 1981, Dunning and Narula 1994, 1996, Ozawa, 1995, 1996). Such lacunae need to be examined more closely.

FDI-based industrial development policies are now commonplace among developing countries. Although there has been a growth in the global FDI flows, there is also increased competition for certain kinds of foreign capital, particularly those that provide opportunities for indigenous spillovers of technology and organisational capability. This has led to locational tournaments, which in certain instances, have led to a dissipation of potential net benefits from MNE activities, at least in the short and medium term (McIntyre et al 1996, Mytelka 1996). Moreover, in a global world, competition between core and peripheral economies for a finite number of discrete (i.e., indivisible) investment projects, will, if the $\mathrm{L}$ advantages are similar, be 'won' by the government with the biggest financial incentives and subsidies. Developing countries are generally not in a position to win such tournaments. The 
improvement of relatively fixed $\mathrm{L}$ advantages is the only feasible means for maintaining a sustainable FDI assisted development strategy. One important means to do so is by optimising the intra-country spatial distribution of economic activity, and by encouraging clusters to attract mobile investment. MNEs, in turn, are also looking for specialised clusters that provide particular kinds of scarce assets to advance their own competitiveness.

This paper is organised as follows. The following section places this paper in context, by examining the need and plausibility for different frameworks for different groups of countries. We then discuss the relationship between the motives of foreign production and the changes in opportunity costs to both developing host country governments and MNEs. Next, we proceed to explain how globalisation has influenced $\mathrm{O}$ and $\mathrm{L}$ advantages. The final section presents some policy implications and conclusions.

\section{ANALYTICAL FRAMEWORK}

The economic relationship between MNEs and democratic national governments is governed by a fundamental difference in the objectives of each. The MNE, as with most private economic entities, desires to maximise the welfare of its owners -wherever they may be located- while the national government wishes to do the same for the constituents within its jurisdiction. Although not a zero-sum game - even where the relationship is not confrontational - the failure to find common ground often results in a sub-optimal outcome for both parties. Nonetheless there is a greater alignment in the interests of the two parties than there used to be. As both countries and firms seek to upgrade their productivity and/or competitiveness, by and large, the only real disagreements that remain concerns the distribution of the costs and benefits of inbound FDI - including those of increased interdependence with the rest of the world. This represents a thorny issue, which to some degree is determined through negotiations between the two parties, and their relative opportunity sets.

It is obvious that these issues go well beyond those of economics and business; and must necessarily include socio-political considerations as well. This is particularly the case with globalisation, which has increased the vulnerability of hitherto relatively closed economies to the external shocks and influences from the world economy at large. This has long been the case for most Triad countries, and is becoming increasingly so for developing countries. In addition, as Stopford and Strange (1991) well illustrate, firm-government interaction is also influenced by the dynamics of government-government and firm-firm relationships. 
It is not our intention here to review the literature pertaining to the shifting political economy of MNE-government relations: this has been tackled elsewhere ${ }^{3}$. In this paper, we are primarily interested in probing how globalisation has changed the way in which developing country governments interact with MNEs, as the latter play an increasingly significant role in their economies. For example, the ratio of inbound FDI flows to gross fixed capital formation (GFCF) in developing countries increased from 3.2\% in 1990 to $8.2 \%$ in 1995 (UNCTAD 1997) ${ }^{4}$.

\section{*******FIGURE 1 ABOUT HERE*******}

Several attempts have been made to explain the bargaining relationship between MNEs and governments, the two most notable being Lecraw and Morrison (1991) and Rugman and Verbeke (1998) $)^{5}$. Essentially, the basic concept is that relative bargaining positions of the two parties are based on the opportunity costs as perceived by the MNEs of their $\mathrm{O}$ advantages, and that of the $\mathrm{L}$ advantages offered by the countries in which they are contemplating an investment; and that of host countries of their L advantages and that of the $\mathrm{O}$ advantages offered by the foreign investors. The primary aspects of the relationship as proposed by Lecraw and Morrison are laid out in Figure 1. This model is not dynamic, in the sense that it does not examine the path of the changing opportunity sets of either party. For example, the liberalisation of markets has had a particularly dramatic effect on most (both Triad and non-Triad) countries, which have experienced massive deregulation, privatisation and the reduction of trade and investment barriers over a span of a decade (or less). Nor does it dwell on a second dynamic: viz, the differences in the opportunity sets of different groups of countries.

The point we wish to emphasise here is that the development path and economic and social objectives of a country is, at least in the early stages of its development, strongly dependent on the specific resources, institutions, economic structure and political ideologies and social and cultural fabric of countries. The kind of FDI activity they might attract (or wish to attract), too, are different. Indeed, these two issues are closely related. Globalisation has made the differences between groups of countries become more rather than less noticeable, even though, simultaneously they are becoming increasingly interdependent. Our primary thesis is that the bargaining framework of Lecraw and Morrison needs to be contextualised if it is to be operationally testable. Although every individual negotiation is a unique event, the type of investment, and the stage of economic development of the host country do allow us to generalise that the situation faced by the least developed countries is fundamentally different 
from the catching-up countries such as the newly industrialised countries (NICs). The opportunity sets faced by the latter group, while similar to the Triad countries (and from whose perspective the bargaining framework was originally developed), also remains distinct. We develop our argument regarding the existence of three distinct groups by relating it to the investment development path (IDP), a framework which postulates that the relationship between FDI and economic structure of countries can be usefully analysed by categorising their evolution through five stages (e.g., Dunning 1981, Narula 1996). Our primary interest throughout this paper will be the developing countries with particular focus of the stage 1 and 2 countries of the IDP that have 'fallen behind'. Throughout the rest of this paper, references to 'falling behind' countries, 'least developed' countries and 'stage 1 and 2 ' countries will be used interchangeably.

\section{Understanding the heterogeneity of developing countries and its influence on their $L$ advantages}

In Figure 2 we present some bullet points of how the MNE/country bargaining situation has changed with globalisation and how this has affected different countries. Developing countries do not represent a homogenous group, and this situation has been exacerbated by the effects of globalisation. The heterogeneity and uneven growth and development of countries may be explored from several perspectives. The literature on economic catch-up and convergence ${ }^{6}$, for instance, tends to categorise countries into three broad groups. The first consists of the wealthy industrialised countries which, over the last two decades, have experienced a convergence in income levels, consumption patterns and technological capabilities. The second comprises the more advanced industrialised developing countries (primarily the Asian NICs), which are catching up and converging with the first group. The third category is made up of a large number of poorer developing countries, which far from converging with the first and second group are diverging from them, either because they have 'fallen behind' relative to the first group, or because they have 'stumbled back' in both a relative and absolute sense (Hikino and Amsden 1994). Put another way, the homogeneity among markets that is usually associated with globalisation has occurred only partially, and in a very selective way.

$* * * * * * *$ FIGURE 2 ABOUT HERE*******

Similar trends have been noted in the case of FDI. Studies on the relationship between inward and outward FDI and the economic development of a country suggests five stages of 
development, a brief description of which are given in Table 1. at a micro-level, it is now axiomatic that different motives underlie FDI, and this is associated with the industrial restructuring process which also follows a distinct pattern. This relates to the work of Chenery and associates, and with regards to FDI to the work of Dunning (1981), Dunning and Narula (1994, 1996), Narula (1993, 1996), Ozawa (1995, 1996) and van Hoesel (1999). Despite FDI flows to developing countries having grown several-fold over the past two decades, the relative share to developing countries (if one excludes the petroleum exporting countries) increased from $13.8 \%$ of the world total to $15.2 \%^{7}$. Table 2 gives details of the changes in the GDP per capita and inward FDI stock per capita of countries, classified according to the World Bank income groups. Although this classification is not entirely consistent with the IDP stages, there is considerable overlap, sufficiently so to illustrate our thesis. This data confirms recent work (e.g., Narula 1996, Dunning and Narula 1998, Dunning et al 1998) on the convergence and divergence phenomena in the case of FDI. While the inward FDI stocks per capita of the low-income and lower-middle income countries has increased by a factor of 3.6 between 1980 and 1995, that of the upper-middle and high income groups has increased by a factor of about 4.4 over the same period. As a result, the gap between the poorest countries and the high income countries has increased: the ratio of their average FDI levels has increased from 259 in 1980 to 308 in 1995 (Table 2). A similar trend is noted for the lower-middle income group. The majority of these countries are in stage 1 and stage 2 . In addition, they have diverged as a group away from the industrialised countries (stage 4 and 5: high-income countries in Table 2) with only a handful of countries at stage 3 (upper-middle income countries in Table 2) experiencing convergence and catch-up, both in terms of income levels and FDI stocks.

$* * * * * * *$ TABLE $1 \& 2$ ABOUT HERE*******

With the increasing reliance of less developed countries on FDI as a source of capital, technology and knowledge (UNCTAD 1997), there is increasing likelihood that there will be further polarisation of the world economy and widening of the gap between the Triad and the bulk of developing countries. In addition, despite the fact that the role of MNEs in some of the stage 1 and 2 countries is increasing - notably in South East Asia (Mason 1998) opportunities for sequential investments are limited, especially in higher value added activities and sectors which provide the most significant potential spillovers (Blomstrom 1989). In an analysis of the effects of global integration on development, Gray (1996) predicts that as globalisation proceeds, the marginal net benefits derived by the least developed 
countries from international involvement will decline. He suggests that the costs of marginalisation are self-reinforcing in that the inability of these countries to attract the kinds of inward FDI which result in positive spillover effects, is also accompanied by fewer opportunities for exports and inflows of portfolio capital.

It is important to note that the IDP framework is used here only as a general paradigm within which to understand the linkage between motives, kinds of FDI and the economic structures of countries; and, in consequence, the difference in the bargaining positions of countries. Essentially, globalisation has made many of the L advantages of countries and the $\mathrm{O}$ advantages of firms increasingly knowledge-intensive. Some of these advantages have become more mobile, others less so. Moreover, it would seem that these same advantages have become more interdependent of each other. For example, a firm's $\mathrm{O}$ advantages in time $\mathrm{t}+1$ may be dependent on the locational profile of its assets in time $t$, while a country's $\mathrm{L}$ advantages in time $\mathrm{t}+1$ may be influenced by its ability to attract the $\mathrm{O}$ advantages of foreign firms in time t. While it is true that there is considerable variation in a country's international investment position between countries at the same stage of development, depending on their economic and political systems, and resource endowments, there are broad similarities that allow us to generalise.

It is to be noted, nonetheless, that these development stages may overlap, precisely because of the various economic and industrial policy options selected. Industrial policy where certain industries are selected for rapid growth by focused investments through intensive development of created assets can and do accelerate the movement of countries through the IDP (van Hoesel 1999). The examples of both the more advanced industrialised countries (such as the NICs) and the second tier emerging economies, particularly Malaysia and Brazil illustrate this. Attracting specialised FDI to a particular sector can alter the sequence of industrial upgrading (Williamson and $\mathrm{Hu}$ 1994), because specialised FDI may help improve the created assets associated within a sector (say consumer electronics production). Created assets in this one sector may have significant knowledge flows externalities in another (say micro-electronics design), which in turn may represent significant input to another sector (say software development). But this assumes the presence of a virtuous circle, and the development of appropriate clusters.

We accept, of course, that inbound FDI does not always play a decisive role in this process of industrial upgrading, or the development of clusters. Clusters may develop without significant MNE intervention, as illustrated by the case of Korea where its large domestic conglomerates have acted as the main engine of growth. Similarly, in Sialkot Pakistan, 
clusters of small firms have developed with world-class expertise in the absence of FDI-based knowledge inflows; they which supply $10-15 \%$ of the world market for high quality surgical instruments, and 50\% of the market in low quality clinical instruments (Nadvi 1996 ${ }^{8}$ )

However, although inward FDI does not represent the only option available to developing countries, but given their urgency and limited resources it may represent the most efficient option. This is for at least four reasons. First, the costs of acquiring technological and organisational know-how through arms-length means is an expensive undertaking, and given the shortage of capital this option is not open to many developing country governments with limited resources. Second, liberalised markets means that firms, ceteris paribus, are likely to be more eager to maintain control of their assets and internalise the market for themselves, either through wholly owned subsidiary or in a joint venture. Exceptions exist, but only where either some strategic reason for the MNE allow for this, the host country has a strong bargaining position ${ }^{9}$, or where the technology has reached the status of a commodity. Third, infant industry protection is de rigeur in creating a domestic sector from scratch, and protected markets are a limited option within the framework of WTO. Fourth, the resources, complementary clusters and assets necessary to support a viable and strong domestic sector are also capital and knowledge intensive. The role of competition in fostering viable domestic industry is a especially important point. This is best illustrated by the failure of the importsubstituting programme in a large number of countries to achieve just this objective.

We wish to emphasise that the availability of foreign-owned capital (either portfolio or direct) for developing countries, is not at issue here. There have been capital flows of both kinds to viable projects in the less developed countries, particularly in extractive industries, and through privatisation programmes. In addition, there has been some low value-adding, labour intensive activities such as garment assembly, which come from attempts to circumvent the multi-fibre agreement. Nonetheless, these activities do not, in general, provide much opportunity for technological spillovers and beneficial externalities. In other words, it is not FDI activities that are hard to attract, but certain kinds of FDI. The next section discusses this assertion some detail.

\section{FDI, MOTIVES AND OPPORTUNITY COSTS}

It is generally acknowledged that there are four main motives for investment: to seek natural resources; to seek new markets; to restructure existing foreign production through rationalisation, and to seek strategically related created assets. These in turn can be broadly divided into two types. The first three represent motives which are primarily asset-exploiting 
in nature: that is, the investing company's primary purpose is to generate economic rent through the use of its existing firm-specific assets. The last is a case of asset-augmenting activity, whereby the firm wishes to acquire additional assets which protect or augment their existing created assets in some way.

Table 1 suggests that due to their lack of indigenous created assets, countries in stages 1 and 2 of their IDP are unlikely to attract much asset-augmenting FDI. Such investment is primarily an activity undertaken in stage 4 and 5 countries, and to a lesser extent, stage 3 countries. While there has been an increase in the location of asset-augmentation activity in some developing countries during the last decade, this continues to be the exception rather than the rule. This is simply because the human resources, technological capabilities and organisational skills that these countries (or their firms) possess, tend to be in relatively lowtechnology and natural resource intensive sectors which have become 'generic' over time (Dunning et al 1998). Indeed, it is often the case that developing country MNEs locate subsidiaries in major clusters of activity in locations in stage 4 and 5, in order to augment their own $\mathrm{O}$ advantages. In the case of strategic technology partnering, an important means by which asset-augmentation is undertaken, Freeman and Hagedoorn (1994) and Narula and Sadowski (1998) both show that with the exception of a few developing countries in stage 3 of their IDP -notably the Asian NICs and China - relatively little technology partnering involves developing country firms. MNE activities in stage 1 and stage 2 countries tend to be in asset-exploiting activity, and as such, asset-augmenting FDI tends (with a few exceptions) to be rare. There are exceptions to this generalisation, for instance, where a MNE has established a location as a regional centre (such as Unilever's use of Thailand as a specialist regional $R \& D$ centre for personal products) or in rare cases, where immobile L advantages is in the form of a cluster of highly skilled but relatively inexpensive labour that helps complement the intellectual capital and markets of MNEs, as in the case of Bangalore in India for the design of software.

\section{$\underline{\text { Resource seeking FDI }}$}

For many years, such investment has been directed to serving international markets. Resource seeking FDI is a case where created asset type L advantages do not play a significant role in determining FDI inflows. Simply put, where a region or country possesses an absolute advantage in a given scarce resource, the government of that location is in a strong bargaining position. Where the resource sought is a natural one, the marginal cost of its extraction to both parties is close to zero. As such, the location is able to generate economic rent depending on the resource's rarity and accessibility in other locations. Most other 
resources, where the advantage is a comparative one, do not maintain a steadily low marginal cost to governments. The cost of utilising such resources rises relative to other locations as country moves along its IDP. Thus they do not attract inward FDI with the same interest at all stages of the IDP. The case of unskilled labour is one example. The location of labour intensive production becomes steadily less attractive to an MNE as the costs of this input rise, particularly so where productivity improvements fail to match wage cost increases. The leverage in such cases lies increasingly with the MNE, as cross-market liberalisation may enable numerous other locations in several countries to offer similar 'generic' and (easily) replicable L advantages (McIntyre et al 1996).

Its international nature means that, as far as resource seeking FDI per se is concerned, there is relatively little difference in the bargaining positions between developing and developed countries. However, since resource-seeking investment generally (but not always) implies low-value adding activity and low capital expenditure on plant and equipment (extractive industries being the exception), FDI is less 'sticky', i.e., more footloose. In general, a purely resource-seeking investment is not normally tightly integrated into the investing firm's organisational structure: indeed MNEs rarely engage in complete internalisation of raw material markets; they prefer instead to conclude non-equity agreements with foreign firms, or purchase their inputs at arms-length prices.

In general, FDI in stage 1 countries is often almost entirely resource seeking. Since there are few other L advantages to offer MNEs, this is often the only kind of FDI present. Where vertical forward integration and further value adding does occur (perhaps because of developments in L advantages as the country moves to stage 2), either to exploit markets or to access other L advantages, the 'stickiness' of the investment increases, thereby strengthening the bargaining position of the host government. Both market-seeking and efficiency seeking investment imply higher integration within the MNE, and a higher level of commitment as well as a higher degree of embedment.

\section{Market-seeking FDI}

Market seeking FDI only gains prominence in situations where the local or adjacent markets provide access to significant opportunities to achieve production economies of scale, a situation most often experienced in the latter part of stage 1 and from stage 2 onwards. This requires not only a sizeable population, but also the ability of the market to support (within a reasonable time frame) the expected demand on which the investment is based. In addition though, there is often a 'follow-the-leader' strategic response by other firms, whereby a market that might have supported two or three competitors is inundated with a larger number 
of new entrants than the market can efficiently support. The case of both the Chinese and the Indian automobile market represent examples of such a scenario, where despite the potential for high demand levels, few participants are actually able to make a profit. This is not the case with all sectors - investments in food and personal products for instance are much more likely to achieve economies of scale, since these products have a relatively low income elasticity of demand. Indeed, the automobile industry may represent a special case in these countries, for what is now described as aggressive market-seeking investments in developing countries in many cases began life as defensive import-substituting investments. These were only permitted under certain stringent conditions, but the MNE normally expected to have access to a captive protected market in return.

Market seeking FDI, by it nature, is based on a single central L advantage. Its presence or absence is stage-dependent, but is essentially an exogenous event, with one exception. Membership of a free trade area allows countries that have small domestic markets to expand their de facto market size. In such situations, however, several formerly sovereign markets become integrated, and the choice of location then rests on other $\mathrm{L}$ advantages. This may have detrimental effects too: once sanctions against South Africa were lifted, a certain hollowing out of market seeking FDI in neighbouring countries was observed, as a result of their free trade agreements with South Africa.

\section{Efficiency seeking and strategic asset-seeking FDI}

These two types of investment are similar in that they both normally require a certain threshold level of created assets, and are generally regarded as being associated with the process of globalisation. It is no surprise that they are generally associated with countries at the latter end of stage 2 onwards, but, especially in the case of asset-seeking FDI, with the industrialised countries.

As such, efficiency seeking investment in the least developed countries is an ambiguous concept, although, for many years, MNEs have engaged in export-oriented resource-seeking investment, which is de facto efficiency-seeking FDI. Moreover, efficiency investment - in the sense that different aspects of manufacturing activity are located in particular locations to exploit the economies of cross-border specialisation and the uneven distribution of immobile created assets- is a relatively new phenomenon

In both of these types of investments, the role of sub-national clusters and the agglomeration of related activities is significant. The bargaining positions of countries that are home to centres of agglomeration, or indeed, possess the necessary science and technology infrastructure necessary to attract asset-augmenting FDI, are considerably different from 
countries which primarily attract asset-exploiting FDI. It is to be noted that even where centres of excellence or agglomeration exist in a given industry, this does not imply that further knowledge intensive investments will be attracted to the same location by virtue of a single cluster existing, unless clear spillovers or externalities exist. Nonetheless, countries (or regions within countries) that have (the basis for) agglomerative economies are the ones likely to be in a strong bargaining position. This was originally the case for export processing zones (EPZs). It now applies to higher value adding activities - even in stage 2 countries such as India- but only where such L advantages are perceived by MNEs to efficiently complement their own core competences.

\section{HOW GLOBALISATION AFFECTS O AND L ADVANTAGES}

In developing a clear understanding of the changes deriving from globalisation per se, it is necessary for us to highlight how the phenomenon has affected the $\mathrm{L}$ advantages of countries (both developing and industrialised), and the nature of the opportunity sets available to developing countries in general. At the same time, these same forces have influenced the nature of the $\mathrm{O}$ advantages of firms and their need and willingness to internalise the markets for them. To some extent, at least, the adoption of outward-looking, export-oriented policy stances by developing countries has been inspired by the success of relatively rapid industrialisation by the Asian NICs. However, the circumstances under which these countries achieved their rapid growth are closely related to the geo-political and economic situation of the post WW2 era. These circumstances cannot be easily replicated in this age of globalisation and the current international political economy.

Underlying the shift in the bargaining power of national governments vis-à-vis foreign MNEs, are two inter-related phenomena. First, there has been a significant reconfiguration in the way both MNEs conduct and coordinate their international operations. Second, there has been a fundamental change in the nature and type of location-specific assets of host countries which MNEs are interested in accessing. Not coincidentally, these changes are directly associated with the economic changes associated with globalisation, and especially with the introduction and adoption of new technologies as well as the renaissance of market-based capitalism.

*******TABLE $3 \& 4$ ABOUT HERE******* 
Table 3 and 4 summarise how these changes in the world economic environment are likely to have influenced the opportunity sets facing both MNEs and governments. However, as we have already emphasised, the heterogeneity of developing countries implies that the general picture set out in these tables disguises certain rather important nuances pertaining to the changes in the nature of opportunity costs that have special reference to the least developed country governments.

\section{New Technologies}

The growth of new technologies has had a significant impact on the locational preferences of MNEs. While technological breakthroughs have been rife, not all have the same direct causality with globalisation as information and communications technologies (ICTs) are considered to do, but are nonetheless associated with it. Of particular note are developments in the fields of new materials, biotechnology, aerospace technologies optical technologies. $\mathrm{ICTs}^{10}$ in particular have dramatically shrunk the economic distance between nation states, and have fostered a series of generic productivity improvements. We outline below how new technologies have influenced the competitive advantages of firms and countries.

\section{(a) New technologies and the $\mathrm{O}$ advantages of firms.}

Table 3 presents some of the primary effects of new technologies on the $\mathrm{O}$ advantages of firms. In particular, we would highlight two main issues:

(i) Improved coordination of intra-firm and inter-firm activities. It is a fundamental feature of international production that cross-border market failure exists in the supply of intermediate goods and services, and especially intangible assets. New advances in ICTs have reduced the cost of acquiring and disseminating knowledge and information in two main ways. First, information about both input and output markets is more easily accessible. This allows firms which previously could not engage in international business transactions to do so ${ }^{11}$. Second, MNEs are better able to integrate the activities of their foreign affiliates through the use of these technologies, and to more quickly respond to changing demand and supply conditions in the countries in which they operate. Taken together, these transaction cost-reducing processes are enabling international production to be more efficiently organised across borders. They are also prompting more rationalised and strategic asset-seeking value-added investment activity by MNEs.

While these new economies of common governance are of particular references to integrated MNEs, multi-domestic MNEs are also able to utilise regional similarities and 
develop 'hub and spoke' approaches, and exploit scale and scope economies between and within regions (Buckley and Casson 1998). Such options allow firms to hedge investments, but are only possible as a result of the reduced monitoring costs associated with ICTs.

There have also been substantial cost-savings in the coordination and monitoring costs associated with inter-firm networks. This growing use of networks, both intra- and inter-firm, is one of the primary features of the age of alliance capitalism (Dunning 1995). The number of strategic alliances, joint ventures, $R \& D$ consortia and the like has experienced rapid growth, both within and between countries (Hagedoorn and Narula 1996), but mainly among the Triad countries. One of the main advantages of improved intra- and inter-firm coordination, is the ease with which MNEs are able to respond to changes in demand and supply. In general, this has meant that firms pursuing multi-domestic strategies can now practice a policy of regional rationalisation, which, in principle, should benefit both the participating countries and the MNE.

(ii) Rapidity of innovation in new technologies has led to truncated product life cycles as new or modified products are more rapidly innovated and manufactured. Firms need both to be able to undertake technological developments and to bring them to market much more speedily than was previously the case. Computer-aided design, 'flexible' manufacturing systems and computer-aided manufacturing have further reduced the set-up costs and time taken to bring to market a new product. Although this has led to a reduction in fixed costs, these technologies are not costless. Shortened product life cycles, for example, often require a relatively high $R \& D$ intensity if firms are to remain competitive. They also suggest that innovating firms need to recoup these fixed costs, before their technology becomes redundant, ${ }^{12}$ often by expanding its overseas markets. Once again, target markets tend to be the industrialising and industrial economies, rather than the diverging developing countries, where multi-domestic strategies still prevail, and whose markets tend to receive products for which the R\&D costs have already been amortised.

\section{b. New technologies and the L advantages of countries}

Table 4 discusses the effects of new technologies on the $\mathrm{L}$ advantages of countries. Our objective here is to focus on the special case of the developing countries, and we highlight some of these differences here.

One of the primary means by which the L advantages have been affected by new technologies has been the emergence and development of entirely new industries, which have generated new sources of employment. The extent to which these developments have affected 
the ability of developing country firms to catch-up is not as acute as with more established sectors. This because in fundamentally new technologies there is not likely to be as large a 'gap' between the lead and lag countries. Indeed, some stage 2 countries - as have most of the stage 3 countries - have successfully engaged in a 'niche' strategy by specialising in the production of very specific new technologies as a way of upgrading their competitiveness the often cited example of India's burgeoning software sector and the focus of other nations (e.g., Cuba) in biotechnology is another (Acharya 1995). However, the failure of the majority of developing countries to exploit these new technologies has acted as a centripetal force, and has encouraged the centralisation of production by MNEs. It should be noted, however, that the opportunity costs of national governments in pursuing a competence in new technologies are quite high, both in terms of creating the necessary infrastructure- including clusters of related activities- and sustaining the necessary macro-organizational policies and financial incentives over an extended period of time. In the main then, the smaller and/or poorer developing countries cannot afford to invest in several niches simultaneously, and as such the question of technological forecasting (i.e., picking the 'right' sectors) becomes crucial.

The relatively low costs to entry are not uniform for all new technologies, however. Most sub-sectors of ICTs, for instance, are highly capital intensive, and are built on existing technologies that are well established and highly competitive. The failure of countries such as Korea in entering and maintaining a strong position memory chips, or Taiwan's Acer in achieving a competitive position in the personal computer industry illustrate this well (Ernst 1998).

Indeed, these types of sectors are the sort of industries where developing countries are interested in developing and would like to attract inward FDI. Triad based MNEs continue to dominate such sectors, and although such firms do engage in value-added activities in developing countries, they tend to concentrate these in a few locations where the appropriate infrastructure and created assets are available. The failure of the majority of the stage 1 and 2 countries to create the kinds of assets - especially intellectual capital, organisational capability and infrastructure facilities- which MNEs need to complement their own $\mathrm{O}$ advantages, underlies the limited extent to which affiliates in these countries have been involved in the process of rationalisation.

Reduced transaction costs due to ICTs has had a much more limited effect on the L advantages of the least developed countries. Much of the FDI in stage 1 countries tends to be natural resource-seeking. These sectors have not benefited greatly from reductions in crossborder transaction costs due to ICTs. Nonetheless, there are some such benefits. First, 
information about policies, incentives and procedures are much more widely disseminated. Second, they are better able to coordinate activities within their countries (between, say, regions that are competing for investment) and between various arms of policy makers and agencies through one-stop shopping (Wells and Wint 1993).

The truncation of life cycles has meant that developing countries that have made investments in certain specific types of created assets may not achieve a realistic return on their high fixed costs by the time (or if) the technology becomes obsolete. Furthermore, shifting to a new technological paradigm takes time, as country-specific changes must be made at all levels, from macro-organisational policy to educational curricula, and such high fixed costs may not represent an option for developing countries.

\section{Renaissance of Market-Based Capitalism and Economic Liberalisation}

The 1980s were a decade of considerable ideological and economic upheaval. In particular, mention might be made of three interconnected events. First, the cold war ended. Since 1989 more than 30 countries have abandoned central planning as the main mode of allocating scarce resources. Second, over 80 developing countries have liberalised their economic policies from inward looking, import-substituting regimes towards outward looking, exportoriented policy regimes. Between them, these two developments have led to a softening of attitudes of national governments towards inward FDI, the privatisation of state owned enterprises, and the reduction of structural market distortions. MNEs are now actively involved in, and have access to, an unprecedented number of countries. This trend is a continuing one that has deepened during the 1990s.

Third, there has been an across-the-board liberalisation of cross-border markets due to (i) (supra-national) regional and inter-regional free trade agreements and protocols, e.g., the establishment of the basis for the European single market, NAFTA and MERCOSUR ${ }^{13}$, (ii) a range of bilateral arrangements; and (iii) the establishment of new multilateral agencies such as the World Trade Organisation (WTO), and the further reduction of trade-related barriers as contained in the Uruguay round of GATT. As a consequence, all forms of trade have markedly increased over the last decade. In addition, increasing attention is now being given to the setting up of a multilateral framework which will ensure a liberalised environment for the flow of FDI and for other forms of MNE activity.

\section{(a) Liberalisation and $\mathrm{O}$ advantages}

Table 3 presents a bullet list of the main benefits which MNEs have gained from economic liberalisation. Privatisation, in particular, has allowed MNEs to acquire, in one fell 
swoop, fully-operational (albeit often inefficient) firms in countries at relatively low cost, due inter alia to depreciation of exchange rates of the recipient economies ${ }^{14}$. Since the Uruguay Round, average tariffs and non tariff barriers have fallen considerably, and affiliates of MNEs are increasingly accorded national treatment.

In addition, liberalisation, and the establishment of WTO and new protocols on intellectual property rights, have improved the appropriability of intangible assets of MNEs. They have, inter alia, also improved the ability of MNEs to undertake and enforce more armslength, non-equity type agreements.

\section{(b) Liberalisation and L advantages}

Although the effects of liberalisation are easily observed, some of which are outlined in Table 4, the news is not as good for stage 1 and 2 economies, as it is for industrial and converging countries. The increased competition between countries and regions to attract mobile investment has increased significantly. While the level of worldwide outward FDI stocks has also increased, a growing proportion of new investment flows is of an technology intensive and knowledge augmenting kind, and/or requires the use of complementary immobile assets. It therefore tends to be directed to the technologically more advanced developed and developing countries. Because of the widespread liberalisation of foreign investment regimes, there is now a much larger (possibly twice as many as two decades previously) pool of countries offering 'generic' location-specific advantages such as access to natural assets and basic infrastructure. The problem of too many countries chasing too little FDI is exacerbated by the competition between provinces and regions within countries which offer their own set of incentives (Mytelka 1996). National and sub-national governments are therefore under pressure to offer ever increasing investment incentives in order to attract the kind of FDI that they perceive will advance their development strategies. Furthermore, inflows from privatisation often represent a single, one-off phenomenon - in the sense that such inflows may initially generate a large initial infusion of capital, but nothing more. Indeed, because MNEs intend to generate some rents from these investments, the net inflows can be expected to be significantly smaller in subsequent years.

It is important to realise that the process of liberalisation is increasingly becoming an exogenous event, over which developing country governments have less and less control. We elucidate. First, the opening up or liberalisation of any particular market in a country represents an endogenous event. However, the benefit that accrues to the country from this event is a function of how many other countries have also liberalised. Second, membership of supra-national institutions such as the WTO (as well as free trade areas, and other forms of 
economic integration) oblige the participating countries to conform their liberalisation policies to a common standard. Third, membership of a de facto trade and investment blocs can effect a change in policy, since, with increasingly few countries still operating within a command economy or a import-substituting regime, there are few opportunities for such countries to engage in economically sound non-market arrangements.

This erosion of the kind of $\mathrm{L}$ advantages associated with protected trade and investment regimes is having far reaching consequences. Although the benefits of liberalisation in terms of encouraging inward FDI are notable, some MNEs have divested in response to liberalisation where the initial MNE activity has been to overcome tariff and nontariff. Since the conclusion of NAFTA, for example, defensive import substitution FDI in Canada has fallen sharply. Although information on divestment in developing countries has not been systematically collected, it is likely that, since proportionally more FDI prior to liberalisation was defensive market seeking, this phenomenon might be a significant one.

\section{POLICY IMPLICATIONS AND CONCLUSIONS}

Globalisation has fundamentally changed economic realities. One of the primary effects of this has been a reconfiguration of countries into three groups: the least developed countries which have 'fallen-behind', the catching up developing countries, and the developed or 'converged' countries. The process whereby this has happened is a complex one, and in this paper we have outlined the dynamics behind these developments and what it has meant for the relationship between MNEs and developing host country governments, and particularly to the 'falling behind' countries. Prior to this dichotomy of developing countries, a general approach towards understanding the bargaining relationship between countries and MNEs was much more feasible, and even practical. This, we argue, is no longer the case. We explain how changes in $\mathrm{L}$ and $\mathrm{O}$ advantages due to globalisation have influenced the nature and context of MNE-government relations, and why a distinction can and should be made between groups of countries.

Over the last two decades, the opportunity costs of FDI for both host country governments and MNEs has changed. From a MNE perspective, the twin forces of globalisation- new technological developments and liberalisation- have considerably influenced the nature and composition of the core competences of firms. These competences are becoming increasingly mobile, firm-specific and knowledge-intensive. At the same time, MNEs are increasingly seeking to consolidate or advance their global competitive positions, by rationalising their cross-border value-added activities. Inter alia, this is shown by the 
continuing rise in intra-firm trade within MNE systems (UNCTAD 1997). This has been helped, in no small measure, by the reduction in their cross-border transaction and coordination costs due to trade and investment liberalisation.

In the pursuance of these objectives, MNEs - and particularly within the knowledge intensive sectors - are being forced to give more attention to the availability and quality of the largely L-specific created assets of alternative investment sites. It is important to note that not all industries have become equally mobile or globalised. As Stopford (1997) notes, while the optimum size of production may have risen in some industries, making global integration desirable, in other cases, new technologies have reduced the minimum efficient scale. This has meant that MNEs (particularly in industries where external economies through spatial linkages are critical) can become more embedded in local and regional milieus than was previously the case, and, in consequence, they become less mobile.

From a national government perspective, exogenous and endogenous changes in the global economic and political environment have caused a reappraisal of the benefits of openness. Inter alia, this has meant that many developing countries have made a complete volte face in their attitudes and policies towards MNE activity. To some extent, this represents an ideological shift from the traditional inward-looking import-substituting model adopted by many developing countries, where state was perceived to be the primary force behind the creation, utilisation and dissemination of knowledge (Frischtak 1997). At the same time, although the change in policy orientation and the subsequent privatisation of state-owned enterprises has reduced the interventionist role of governments, that of the market facilitating role and the provider of complementary created asset-based location-specific advantages has become more critical (Dunning 1997b, Stopford 1997).

All these changes, however, still do not disguise the fact that national governments and MNEs continue to have different goals. While in general, MNEs are more single-minded and homogenous in their objectives, governments are much more varied in their expectations. The twin goals most host governments seem to have in common are improving capital inflows and development of indigenous know-how. Although these two objectives are not necessarily incompatible, there may in fact be a trade-off between the two.

There is, nonetheless, a much closer alignment in the goals of MNEs and governments in the current world scenario ${ }^{15}$. Although the bargaining position continues to favour the $\mathrm{MNE}$, as far as the developing countries are concerned, and in the least developed countries, increasingly so, the common ground is much greater. 
In addition, globalisation, in as much as it has helped improve cross-border intra-firm coordination of selected activities, this has meant that firm-specific resources and capabilities are more footloose than was previously the case. That notwithstanding, MNEs are aware of the costs of being footloose, particularly so because the improvement of their competitive advantages increasingly depends on augmenting their often-customised firm-specific assets with largely-immobile country-specific assets . The way to do this is through investing over a long term in the synergies that they can derive from immobile assets of the host countriesincluding those from agglomerative economies. In some senses, it can be said that the primary disagreement that remains in the MNE-government relationship is one of how to distribute the rents resulting from MNE activity, both in the short and long run. That is to say, the rent arising from innovatory and restructuring activities of MNEs ought to be considered alongside that arising from improved 'static' allocative efficiency.

Governments are modifying their efforts to attract inbound investment in two major respects. The first is to step up, or offer a new range of financial incentives. This is the route favoured by national and sub-national governments. However, recent research by Mudambi (1995) suggests that while incentives offered in isolation of other $\mathrm{L}$ advantages are not effective, the longer they persist, the more likely that they will have a positive effect. At the same time, there is a danger that due to the increased competition, governments may give away more than the potential benefits that accrue from the MNE activity (Mytelka 1996, McIntyre, et al 1996). This is all the more so, since governments of developing countries (or regions within these countries) must compete with backward regions in industrialised countries and with those of the former centrally planned economies whose infrastructure tends to be far superior, and pockets far deeper than most developing countries. Given the costs associated with offering incentives, and the profusion of locations offering incentives there is a danger, that in an attempt to attract new 'desirable' investors, the net benefits to countries are negative, and worse, the new investors may be treated preferentially relative to existing (and embedded) firms (Mudambi 1998). Given the limited resources of developing countries, this does not represent a viable or desirable long-term option.

The second means, that of identifying and offering unique and non-imitable immobile assets to attract mobile investment is a better long-term solution. To offer the kinds of advantages (e.g., in respect of education and transportation infrastructure) made available by competitive governments is not sufficient; what is needed is the provision of immobile created assets which are 'custom made' to the incoming investors (Peck 1996), or are specific to the country and region seeking the investment (Dunning 1998). Often such assets are 
complementary to each other and need to be spatially clustered if they are to be deployed with optimum efficiency (Storper and Scott 1995). In pursuance of this kind of strategy national governments such as Singapore and Ireland and sub-national governments, e.g., Wales, Northern Ireland, Shanghai, Bangalore, New South Wales, Baden-Wurttenburg and Piedmont- to name just a few- have met with a great deal of success.

The challenge to national governments lies in providing the 'right' kind of immobile assets, and to encourage mobile investments to be locked into these assets, and, in this, there is little difference between the cases of developing, industrialising or industrialised economies. It should be said, however, that for countries in stage 1 and stage 2 , the question is much more urgent, since there is a threshold level which is required to attract even the most basic forms of FDI. In addition, though, if externalities are to accrue from FDI, these are most likely associated with investments which are not only market or efficiency-seeking but which in order to prosper, need to be spatially linked to complementary activities. The idea of enclaves such as EPZs, once quite popular as a means to attract FDI, have had mixed success mainly because their planners often lost sight of the order in which events should have taken place: the development of clusters of economic activity, from which might come welfare benefits, rather than vice-versa. The limited nature of the L advantages offered to MNEs, and the high costs of establishing these zones in remote areas where the necessary support industries were present underlay their failure.

The basic idea of building enclaves is a sound one. After all, developing countries have limited resources to plough into created asset-enhancement, and must therefore pick a few locations to upgrade, just as several countries have targeted selected industries to nurture. The use of FDI as a means to transfer technology is efficient only as long as sufficient absorptive capability of the technologies exists locally (Borensztein et al 1998). Once countries have progressed beyond the threshold in terms of their L-specific advantages, the gradual building up of high grade centres and the development of clusters of economic activity becomes a high priority. This is a task that is fraught with pitfalls, not least because selecting the 'right' industry to target becomes more difficult the closer the country is to the technological frontier. When governments attempt to select preferred industries in which to focus some distance away from the technological frontier (say in differentiated Smithian sectors - see Table 1), the direction in which investment is to be made is obvious since firms at the frontier (i.e., the technology leaders) have already done so $^{16}$ in the past (Narula and Dunning 1998). That is to say, the further a country is from the technological frontier, the easier it is to 'pick' industries that will be successful. The relative success of MITI in picking 
winners in the 1950s and 1960s, and their subsequent less successful interventions in the 1980s and 1990s well illustrates this point. Although there is a danger in investing limited resources in niche sectors which become obsolete, or get replaced by a new technological paradigm, this need not happen if broader sectors are targeted that are complementary to, and help upgrade, existing competencies and skills. The development of Singapore's biotechnology sector illustrates this well (Lall 1997). As Stopford (1997, pg. 473) explains,

"To nurture clusters, work needs to be done to identify specific technologies that can reinforce the position of existing leaders, or that suit the skills of the workforce or even that satisfy the demand that is particularly sophisticated in the nation. Investment in 'market-friendly' aspects of the underlying technologies can, as in Singapore, create a vital base for the building of firm-specific advantages by either local or foreign firms."

On the other hand, in this era of globalised production, it is easier to create clusters from scratch, compared to the traditional view of industrial districts, where all aspects of the value-added chain had to be catered for (Stopford 1997). Because of the abilities of MNEs to locate different parts of their value-added chain in several locations to achieve global efficiency, there is an increased opportunity for specialisation, and to attract MNEs to invest in a niche area. A complementary approach to improving L advantages is to engage in some form of economic integration on a regional basis. However, as Baldwin (1997) notes, most regional trade blocs and other forms of economic integration among developing countries have remained very much a matter of organisation rather than substance (APEC, ASEAN), with a few exceptions (e.g., MERCOSUR).

It is clear that a myriad of approaches to industrial policy have been taken by developing countries to achieve catch-up, but since the economic structure of each country is very path-dependent and idiosyncratic, it is difficult to suggest any one 'best' solution. Given the stakes involved, and the pressures on developing countries to develop unique locationspecific advantages to attract the kind of FDI they need to upgrade their indigenous resources, some sort of interventionist approach seems to be necessary. No self-evident solution exists, because the changing world economic environment makes some of these options impractical, or invalid for particular countries at particular stages of their IDP. For instance, the level of infant industry protection undertaken by Japan or Korea during the early stages of their development is now more difficult to implement, as the level of subsidies that governments can legally provide are now restricted due to multilateral restrictions introduced within the WTO framework. 
It cannot be emphasised too strongly that the means by which countries can develop and maintain strong clusters of economic activity are not well-understood, despite considerable research having been conducted, dating back to Marshall's work on industrial districts ${ }^{17}$. The nature of globalisation adds yet another complication. For instance, financial subsidies by governments to MNEs, especially those that have geocentric structures or who have simply rationalised their activities to seek global efficiency are able to utilise resources provided by one location in another, thereby defeating the objectives of governments.

The creation of centres of agglomeration is a difficult thing to achieve. Indeed, a recent study by Head et al (1994) indicates that agglomeration is determined less by differences in natural resources, labour and infrastructure, but by the presence of other firms. Nonetheless, the presence of a certain minimum level of location-specific advantages (infrastructure and skilled labour) must be necessary as a catalyst to attract these firms to establish themselves in a given spatial area, and most importantly, the presence of domestic firms with the technological capabilities to absorb the spillovers pertaining from the activities of these firms. In addition though, it is clear that the use of incentives and subsidies is no substitute for the presence of created assets, not just because of the inability to absorb spillovers, but also because in locational tournaments involving richer countries, the least developed countries are bound to lose.

\footnotetext{
${ }^{1}$ These features are described in various publications, including UNCTAD (1997), Perraton et al (1997) and OECD (1997).

${ }^{2}$ Notably all kinds of knowledge, organisational and institutional capital.

${ }^{3}$ Dunning (1993) charts the evolution of MNE-government interaction over a 30 year period, and in so doing demonstrates the way in which economic forces are influenced by, and influence, the nature of governmentMNE relationships.

${ }^{4}$ Where the inbound FDI stock as a percentage of gross domestic product (GDP) rose from $8.3 \%$ to $15.4 \%$ over the same period (UNCTAD 1997).

${ }^{5}$ The methodology proposed by Rugman and Verbeke (1998) focuses more on the strategic aspects of the relationship. It encompasses a broader analysis that provides the basis for a more dynamic approach, although it is a general model in that it does not address either developing-country-specific issues, nor how the situation varies between countries. Essentially this model argues that the relationship between MNE and governments is determined inter alia by the degree of symmetry between inward and outward FDI in a given country, the dispersion of firm-specific advantages within MNEs, the strategic approach by MNEs to government policy, and the congruence between MNE and home and host country goals. They include the net direct investment position as a determinant, but do not consider the influence of the absolute levels.
} 
${ }^{6}$ See e.g., Dowrick and Gemmell (1991), Dowrick (1992), Verspagen (1992)

${ }^{7}$ Africa and Latin America fell from 7.3\% and 2.7\% in 1980 to 5.5\% and $0.8 \%$ in 1993 respectively (Dunning and Narula 1998).

${ }^{8}$ For further examples, see Nadvi and Schmitz (1994)

${ }^{9}$ For instance, where the local market is large and the MNE can only get access to other sectors in exchange for technology, or lucrative turn-key or other sub-contracts are included.

${ }^{10}$ Some scholars believe ICTs are initiating a new technological paradigm (Freeman 1987, Freeman and Perez 1988).

${ }^{11}$ Several recent UN studies (UN 1993, UNCTAD 1997) has indicated that there is an increasing number of small and medium enterprises are engaging in FDI.

${ }^{12}$ It can either: (a) sell at a relatively high cost per unit, and/or (b) develop a production process with a low minimum efficient scale of production and/or (c) recoup its investment by acquiring a large market for its products so as to spread its fixed costs, and/or (d) engage in an alliance with another firm (or firms) to speed up, and share the costs of the innovatory process.

${ }^{13}$ There are also non-binding agreements and protocols such as the OECD code of liberalisation of capital movements (which are binding upon member states, but not on non-members) and guidelines for multinational enterprises.

${ }^{14}$ Over the period 1989-93, FDI from privatisation accounted for $\$ 12.2$ billion or $7.6 \%$ of all inflows to developing countries (UNCTAD 1996). Over $75 \%$ of this was directed towards Latin America and the Caribbean, where privatisation accounted for $16.9 \%$ of all inflows to the region. In the case of Central and Eastern Europe, FDI inflows to privatisation schemes amounted to $\$ 7.5$ billion, or $59.7 \%$ of the total FDI inflows to the region.

${ }^{15}$ For a summary of the situation in the 1970s and early 1980s see Dunning (1993) and Wells (1998).

${ }^{16}$ It is however necessary to emphasise the difference between firms that are a distance from the technology frontier, and those that are simply experiencing X-inefficiency. The latter group are simply using an inferior technology, while the former are operating at an earlier stage of the product life cycle.

${ }^{17}$ For a review of the various strands of the literature, see Baptista (1998) as well as other contributions to Swann et al (1998), and Enright (1994, 1998) 


\section{REFERENCES}

Acharya, Rohini (1996) The Biotechnology Revolution, Edward Elgar, Aldershot

Baldwin, R. (1997) The causes of regionalism, World Economy, 3: 865-888

Baptista, R. (1998) Clusters, innovation and growth: a survey of the literature, in G. Swann, M. Prevezer and D. Stout (eds) The Dynamics of Industrial Clustering, Oxford: Oxford University Press

Blomstrom, Magnus (1989) Foreign investment and spillovers: a study of technology transfer to Mexico, London: Routledge

Borenszstein, E. De Gregorio, J. and J.-W Lee (1998) How does foreign direct investment affect economic growth? Journal of International Economics, 45, 115-135

Buckley, P. and Casson, M. (1998) Models of the multinational enterprise, Journal of International Business Studies, 29 (1): 21-44

Dowrick, S. (1992) Technological Catch Up and Diverging Incomes: Patterns of Economic Growth 1960-88 The Economic Journal, Vol 102, pp 600-610

Dowrick, S. and Gemmell, N. (1991) Industrialisation, Catching Up and Economic Growth: A Comparative Study Across the World's Capitalist Economies, The Economic Journal, Vol 101, pp 263-75

Dunning J.H. (1981) Explaining the international direct investment position of countries: towards a dynamic or developmental approach, Weltwirtschaftliches Archiv, 119:30-64 Dunning, J.H. (1993) Multinational Enterprises and the Global Economy, Wokingham: Addison Wesley

Dunning, J.H. (1995) Reappraising the eclectic paradigm in an age of alliance capitalism, Journal of International Business Studies,26(3): 461-91

Dunning, J. H. (1997a) Alliance capitalism and global business, London: Routledge

Dunning, J.H. (1997b) A business analytic approach to governments and globalisation, in J.H. Dunning (ed) Governments, globalisation and international business, Oxford: Oxford University Press, pp 114-131

Dunning, J.H. (1998)Transnational corporations and national governments: a new concord or an uneasy truce?, New Political Economy, forthcoming

Dunning, J.H. and Narula, R. (1994) Transpacific Direct Investment and the Investment Development Path: The Record Assessed, Essays in International Business, March, No 10 
Dunning, J.H. and Narula, R. (1996) The investment development path revisited: some emerging issues, in J. Dunning and R. Narula (eds), Foreign Direct Investment and Governments: Catalysts for Economic Restructuring, London: Routledge.

Dunning, J.H. and Narula, R. (1998) Developing countries versus multinationals in a globalising world: the dangers of falling behind, in P. Buckley and P. Ghauri (eds), Multinational enterprises and emerging markets, London: Dryden Press, forthcoming.

Dunning, J.H. van Hoesel, R. and Narula, R. (1998) Explaining The 'New' Wave Of Outward FDI From Developing Countries, International Business Review, forthcoming

Enright, M. J. (1994), Regional Clusters and Firm Strategy, paper presented to Prince Bertil Symposium on The Dynamic Firm, The Role of Regions, Technology, Strategy and Organization, Stockholm, June 12-15

Enright, M. J. (1998), The globalization of competition and the localization of competitive advantage, paper presented to workshop on The Globalization of Multinational Enterprise Activity and Economic Development, Glasgow, May 15-16

Ernst, Dieter (1998) Destroying or upgrading the engines of growth? The reshaping of the electronics industry in East Asia after the crisis, mimeo, Copenhagen

Freeman C. (1987) The challenge of new technologies in interdependence and cooperation, in Tomorrow's world, OECD, Paris, pp 123-56

Freeman, C. and Hagedoorn, J. (1994) Catching up of falling behind: patterns in international interfirm technology partnering, World Development, Vol 22, pp771-780

Freeman, C. and C. Perez (1988) Structural crises of adjustment, business cycles and investment behaviour, in G. Dosi et al (eds) Technical Change and Economic Theory, London: Pinter

Frischtak, C. (1997) Latin America, in J.H. Dunning (ed) Governments, globalisation and international business, Oxford: Oxford University Press, pp 431-454

Fukuyama, F. (1995) Trust: The Social Virtues and the Creation of Prosperity, London, Hamish Hamilton

Gray, H.P. (1996) Globalization and Economic Development, mimeo, Rutgers University, Newark

Hagedoorn, John and R. Narula (1996) Choosing modes of governance for strategic technology partnering: international and sectoral differences, Journal of International Business Studies 27 (2): 265-284 
Head, K., J. Ries, and D. Swenson (1994) Agglomeration Benefits and Location Choice: Evidence from Japanese manufacturing Investment in the United States, NBER Working Paper no 4767

Hikino, T. and A. Amsden (1994) Staying behind, stumbling back, sneaking up, soaring ahead: late industrialization in historical perspective, in W. Baumol, R. Nelson and E. Wolff (eds), Convergence of Productivity: Cross Country Studies and Historical Evidence, Oxford University Press, New York.

Hoesel, Roger van, (1999) New Multinational Enterprises from Korea and Taiwan, London: Routledge

Lall, Sanjaya (1997) East Asia, in, in J.H. Dunning (ed) Governments, globalisation and international business, Oxford: Oxford University Press, pp 407-430

Landes, David (1998) The Wealth and Poverty of Nations, London: Little Brown and company

Lecraw, D. and A. Morrison (1991) Transnational corporation-host country relations: a framework for analysis, Essays in International Business, No 9, September

Levin, R., Klevorick, A., Nelson, R., and S. Winter (1987) Appropriating the returns from industrial research and development, Brookings Papers on Economics Activity, No 3, pp 783820

Mason, Mark (1998) FDI in the Mekong delta, paper presented to a conference on FDI in Asia, Macau, April

McIntyre, J., R. Narula and L. Trevino (1996) The role of export processing zones for host countries and multinationals: a mutually beneficial relationship? International Trade Journal, 10: 435-466.

Mudambi, Ram (1995) The MNE investment location decision: some empirical evidence, Managerial and Decision Economics, 16: 249-257

Mudambi, Ram (1998) The role of duration in MNE investment attraction strategies, Journal of International Business Studies 29 (2): 239-262

Mytelka, L (1996) Locational Tournaments, Strategic Partnerships and The State, mimeo, Carleton University, Ottawa

Nadvi, Khalid (1996) Small firm industrial districts in Pakistan, Unpublished DPhil thesis, University of Sussex: Brighton

Nadvi, K. and Schmitz, H. (1994) Industrial clusters in less developed countries: Review of experiences and research agenda, Institute of Development studies Discussion Paper 339, University of Sussex, Brighton 
Narula, Rajneesh (1996) Multinational Investment and Economic Structure, Routledge, London

Narula, Rajneesh and John H. Dunning (1998) Explaining International R\&D Alliances and the Role of Governments, International Business Review, forthcoming

Narula, Rajneesh and Bert Sadowski (1998) Technological Catch-up and Strategic Technology Partnering in Developing Countries, International Journal of Technology Management, Forthcoming

OECD (1997) The World in 2020: Towards a New Global Age, Paris: OECD

Ozawa, T. (1995) Structural upgrading and concatenated integration, in D Simon (ed) Corporate Strategies in the Pacific Rim: Global versus Regional Trends, London: Routledge, pp 215-246

Ozawa, T. (1996) Japan: the macro-IDP, meso-IDPs and the technology development path (TDP), in J. Dunning and R. Narula (eds), Foreign Direct Investment and Governments: Catalysts for Economic Restructuring, London: Routledge, pp 423-441

Patel, Pari. and Vega, M. (1998) Patterns of internationalisation and corporate technology: location versus home country advantages Research Policy, forthcoming

Peck, F.W. (1996) regional development and the production of space: the role of infrastructure in the attraction of new inward investment, Environment and Planning, 28: 327339

Perraton, J., Goldblatt, D. Held, D. and McGrew, A. (1997) The globalisation of economic activity, New Political Economy, 2 (2) 257-277

Porter, M.E. (1994) The role of location in competitions Journal of Economics and Business, 1: 35-39

Porter M.E (1996) Competitive advantages agglomerative economies regional policy, International Regional Science Review, 19: 35-39

Rugman, A. and Verbeke, A. (1998) Multinational enterprises and public policy, Journal of International Business Studies, 29 (1):115-136

Stopford, J. (1997) Implications for national governments, in J.H. Dunning (ed) Governments, globalisation and international business, Oxford: Oxford University Press, pp 457-480

Stopford, John and Susan Strange (1991) Rival states, rival firms. competition for world market shares, Cambridge: Cambridge University Press

Storper, M. and Scott, A. (1995) The wealth of regions, Futures, 27 (5) 505-26

Swann, G., M. Prevezer and D. Stout (eds) (1998) The Dynamics of industrial clustering, Oxford: Oxford University Press 
UN (1993) Small and Medium-Sized Transnational Corporations, New York: United Nations UNCTAD (1996) World Investment Report 1995 United Nations: Geneva

UNCTAD (1997) World Investment Report 1997, United Nations: Geneva

Wells, L.T. (1998) Multinationals and developing countries, Journal of International Business Studies, 29 (1): 101-114

Wells, L.T. and A. Wint (1993) Don't stop with the one-stop shop: foreign investment in a liberalising third world, International Executive, 35: 367-384

Williamson, P. and Q. Hu (1994) Managing the Global Frontier, London: Pitman Publishing. Verspagen, B. (1993), Uneven Growth Between Interdependent Economies. An Evolutionary View on Technology Gaps, Trade and Growth, Aldershot: Avebury. 


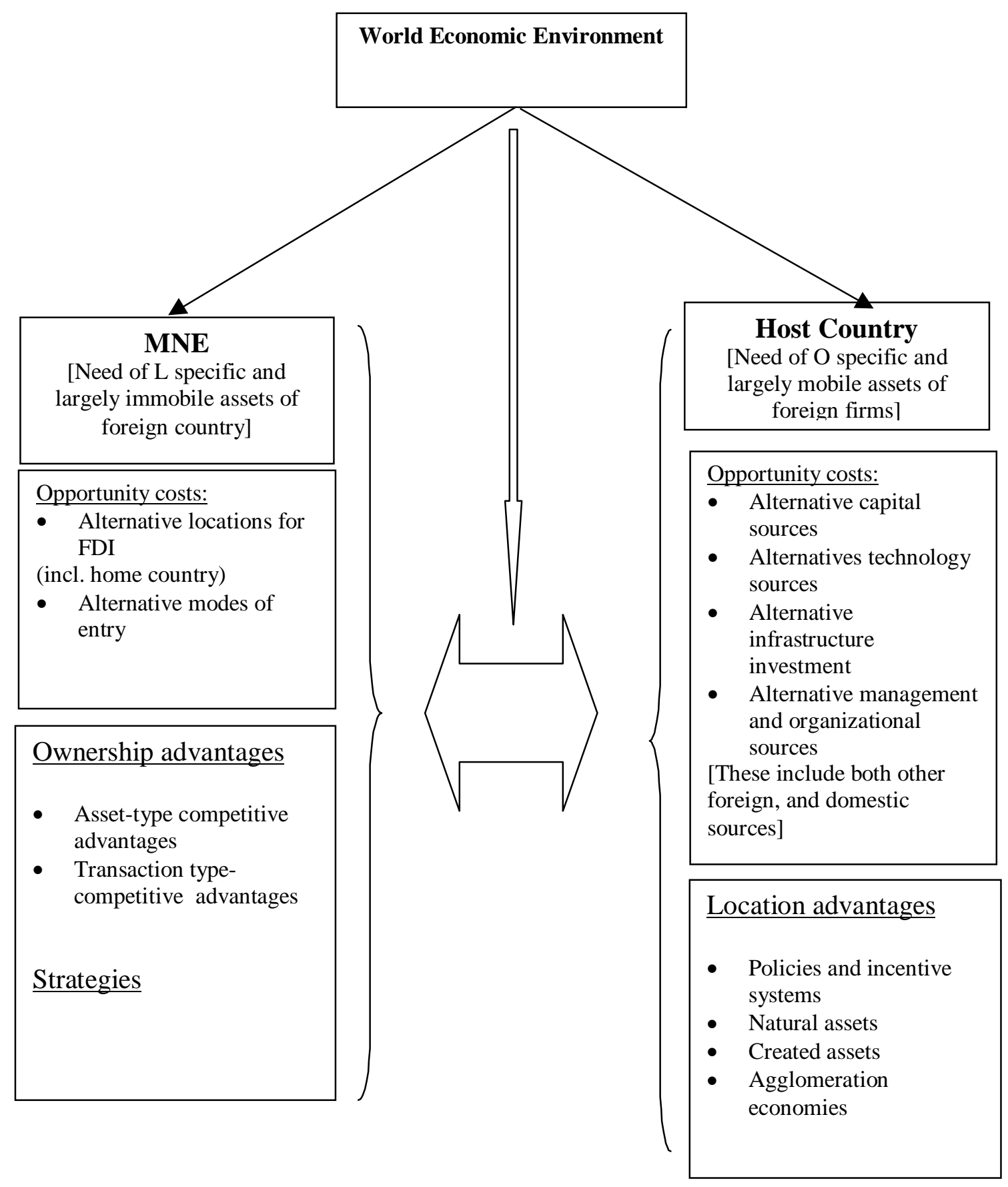

Source: adapted from Dunning (1993) and Lecraw and Morrison (1991)

Figure 1: Host countries and MNEs: a static view of bargaining issues 


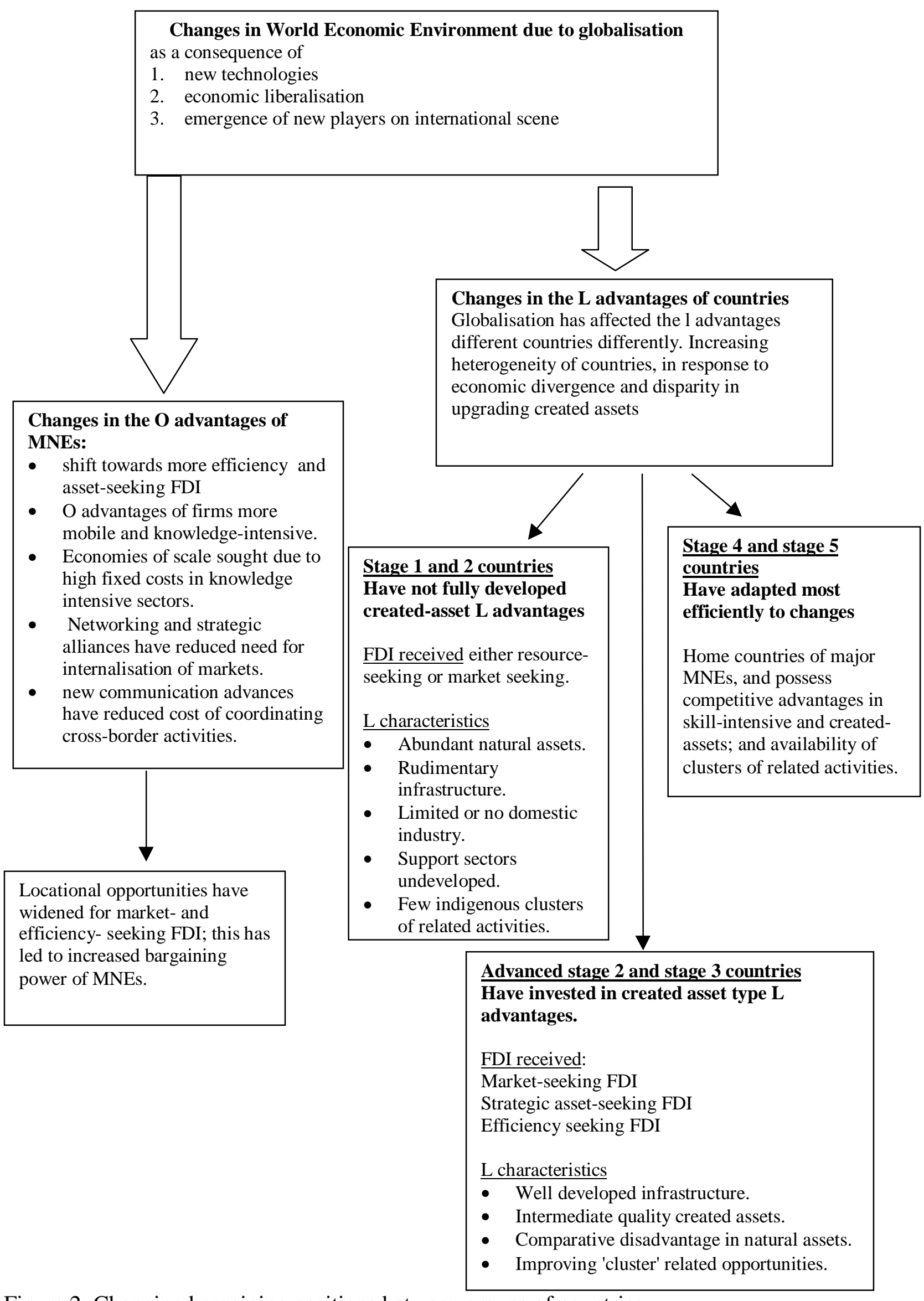

Figure 2: Changing bargaining positions between groups of countries 


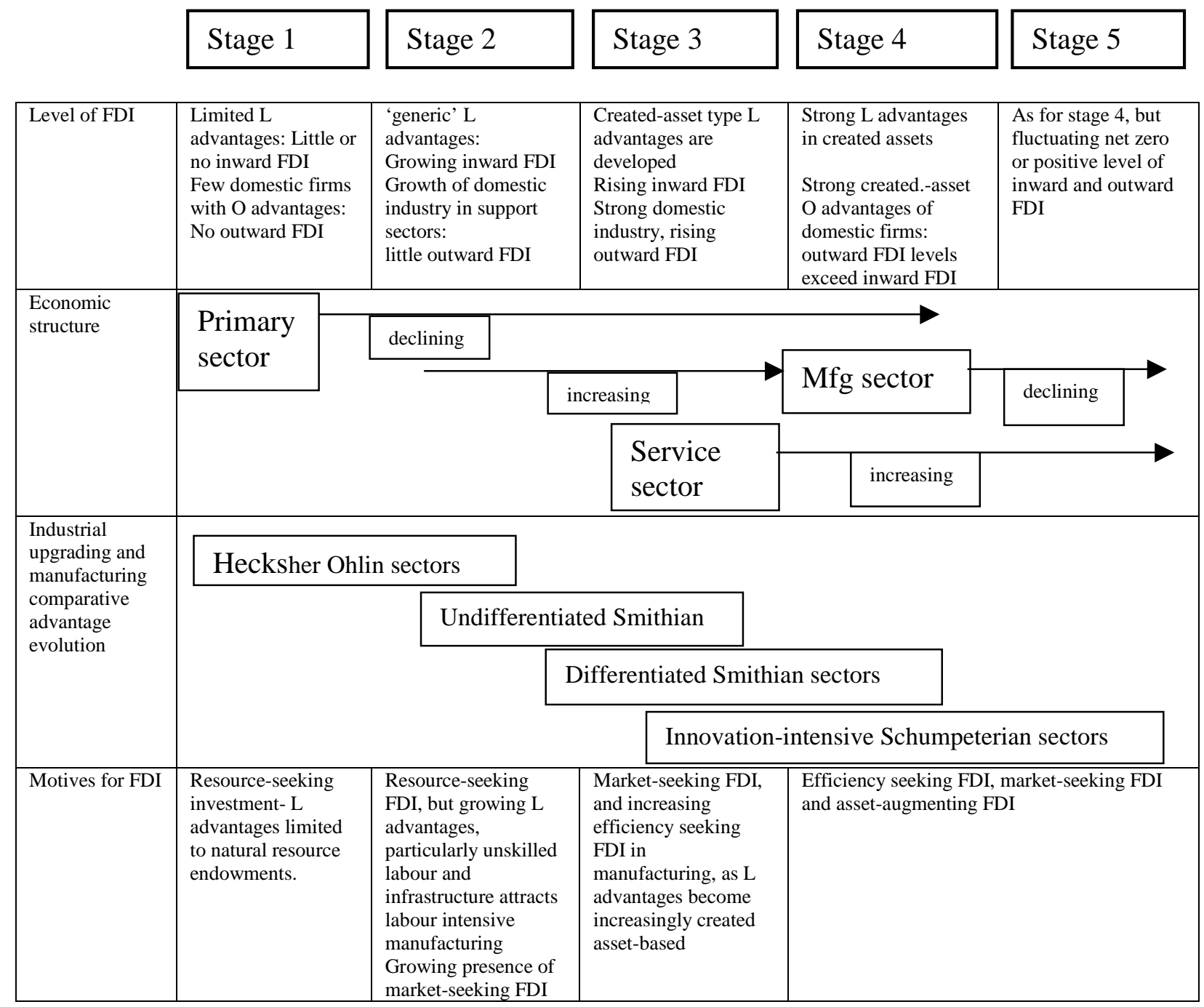

Table 1: the primary relationships underlying the investment development path 


\section{GDP per capita}

Inward FDI stock per capita

\begin{tabular}{|c|c|c|c|c|c|c|}
\hline \multirow{2}{*}{\multicolumn{2}{|c|}{1980}} & \multicolumn{2}{|c|}{$19951995 / 1980$} & 1980 & \multicolumn{2}{|c|}{$19951995 / 1980$} \\
\hline & & & $(n=42)$ & & & \\
\hline mean & 435.2 & 357.4 & 0.8 & 1.4 & 4.9 & 3.6 \\
\hline SD & 320.1 & 163.9 & & 1.7 & 6.1 & \\
\hline \multicolumn{4}{|c|}{ Low-middle income countries $\quad(n=36)$} & & & \multirow{3}{*}{3.6} \\
\hline mean & 1219.1 & 1818.3 & 1.5 & 10.4 & 37.4 & \\
\hline SD & 618.7 & 720.3 & & 12.2 & 39.3 & \\
\hline \multicolumn{4}{|c|}{ Upper-middle income countries $\quad(n=20)$} & & & \multirow{3}{*}{4.4} \\
\hline mean & 3898.3 & 5340.2 & 1.4 & 40.4 & 179.5 & \\
\hline SD & 3576.6 & 1813.6 & & 33.5 & 182.7 & \\
\hline \multicolumn{2}{|c|}{ High income countries } & \multicolumn{2}{|r|}{$(n=32)$} & & & \\
\hline mean & 11780.3 & 22081.8 & 1.9 & 353.7 & 1520.9 & 4.3 \\
\hline $\mathrm{SD}$ & 7254.5 & 8381.4 & & 1643.9 & 6777.0 & \\
\hline
\end{tabular}

Ratio of high income countries FDI pc to that of low income countries.

$259.0 \quad 307.5$

Ratio of high income countries FDI pc to that of low-middle income countries.

$$
34.0 \quad 40.7
$$

Ratio of high income countries FDI pc to that of upper middle income countries.

$$
8.8 \quad 8.5
$$

Sources: $\quad$ GDP and population based on World Development Indicators CD-ROM, World Bank 1997 Inward FDI stock based on UN (1997)

Notes: all countries for which GDP was unavailable for 1980 and 1995 (or close proxy) were excluded. this excludes all former soviet bloc countries, but includes Vietnam and China

Countries were classified according to World Bank criteria for 1995: low income <\$765 GDP per capita Low-middle income, \$766-3035, upper-middle income, 3036-9385, high income: >\$9386

Table 2: Changes in GDP and inward FDI stock per capita,1980 and 1992: evidence of divergence 


\begin{tabular}{|c|c|c|c|c|c|}
\hline & & Triad-based MNEs & & & \\
\hline & & Alternatives in location & Mode of investment & $\begin{array}{l}\text { Asset type } \\
\text { Ownership } \\
\text { advantages }\end{array}$ & $\begin{array}{l}\text { Transaction-type } \\
\text { Ownership advantages }\end{array}$ \\
\hline 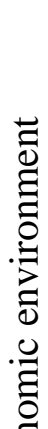 & Liberalisation & $\begin{array}{l}\text { Growing use of efficiency } \\
\text { seeking investment, as MNEs } \\
\text { locate to better exploit } \\
\text { economies of scale and scope. } \\
\text { More options for location of } \\
\text { labour and resource intensive } \\
\text { investment because of DC } \\
\text { liberalisation. } \\
\text { Limited or no change in options } \\
\text { for knowledge-intensive } \\
\text { sectors, and for asset- } \\
\text { augmenting activities. }\end{array}$ & $\begin{array}{l}\text { Easier to enforce non- } \\
\text { equity agreements as } \\
\text { well as arms-length } \\
\text { transactions, especially } \\
\text { within Triad. }\end{array}$ & $\begin{array}{l}\text { Improved property } \\
\text { rights protection for } \\
\text { firms due to WTO, } \\
\text { WIPO. Overall } \\
\text { growth of created } \\
\text { asset based O } \\
\text { advantages. }\end{array}$ & $\begin{array}{l}\text { Improved Ot } \\
\text { advantages for firms } \\
\text { that have rationalised } \\
\text { within economic blocs } \\
\text { (EU, NAFTA) relative } \\
\text { to those which have } \\
\text { not. }\end{array}$ \\
\hline 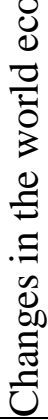 & $\begin{array}{l}\text { New } \\
\text { technologies }\end{array}$ & $\begin{array}{l}\text { Improved access to information } \\
\text { leads to more efficient choice } \\
\text { of location. } \\
\text { Need to be in closer proximity } \\
\text { of related industries to reduce } \\
\text { spatial transaction costs }\end{array}$ & $\begin{array}{l}\text { truncated product life } \\
\text { cycles, need for multi- } \\
\text { technology competencies } \\
\text { also lead to increased } \\
\text { use of alliances. }\end{array}$ & $\begin{array}{l}\text { Increasing mobility } \\
\text { of Oa advantages } \\
\text { New industries have } \\
\text { in some instances } \\
\text { provided an } \\
\text { opportunity to } \\
\text { extend product life } \\
\text { cycle } \\
\text { Higher share of } \\
\text { knowledge content } \\
\text { in O advantages. }\end{array}$ & $\begin{array}{l}\text { Improved cross-border } \\
\text { communication results } \\
\text { in more optimal intra- } \\
\text { firm coordination, and } \\
\text { integration. }\end{array}$ \\
\hline
\end{tabular}

Table 3: the changing nature of the world economic environment and the opportunity sets of MNEs

\begin{tabular}{|c|c|c|c|c|}
\hline & COUNTRIES & & & \\
\hline & $\begin{array}{l}\text { Alternatives for technology and } \\
\text { capital }\end{array}$ & $\begin{array}{l}\text { Policies and incentive } \\
\text { systems }\end{array}$ & Natural assets & Created assets \\
\hline Liberalisation & $\begin{array}{l}\text { More alternatives in terms of } \\
\text { technology, as well as } \\
\text { increased modes of transfer }\end{array}$ & $\begin{array}{l}\text { Policies become increasingly } \\
\text { standardised among } \\
\text { countries. } \\
\text { Subsidy limits from WTO } \\
\text { membership reduces O } \\
\text { advantages of domestic firms }\end{array}$ & $\begin{array}{l}\text { Natural assets } \\
\text { increasingly a } \\
\text { commodity, except } \\
\text { where substantial } \\
\text { comparative or } \\
\text { absolute advantage } \\
\text { exists. }\end{array}$ & $\begin{array}{l}\text { Increasing mobility of } \\
\text { highly skilled workforce } \\
\text { Created assets increasingly } \\
\text { firm-specific }\end{array}$ \\
\hline New technologies & $\begin{array}{l}\text { Opportunity for leapfrogging- } \\
\text { smaller stock of knowledge. } \\
\text { Improved ability to find } \\
\text { alternatives due to ICTs }\end{array}$ & $\begin{array}{l}\text { More inter-country and inter- } \\
\text { region competition on } \\
\text { incentive schemes. } \\
\text { Easier for firms to transfer } \\
\text { price due to ICTs, and reduce } \\
\text { tax burden. }\end{array}$ & & $\begin{array}{l}\text { Truncated life cycles mean } \\
\text { that L advantages may } \\
\text { become obsolete. High } \\
\text { fixed cost in upgrading } \\
\text { technological } \\
\text { infrastructure and national } \\
\text { systems of innovation } \\
\text { regularly. }\end{array}$ \\
\hline
\end{tabular}

Table 4: the changing nature of the world economic environment and the opportunity sets of host countries 